\title{
ANAEROBIC DIGESTION OF OLIVE MILL WASTEWATER
}

\author{
P.S. BLIKA ${ }^{1,2}$ \\ K. STAMATELATOU ${ }^{1,2}$ \\ M. KORNAROS ${ }^{1}$ \\ G. LYBERATOS ${ }^{1,2, *}$
}

\author{
${ }^{1}$ Dept. Chemical Engineering, University of Patras \\ 26504 Patras, Greece \\ ${ }^{2}$ Institute of Chemical Engineering and High \\ Temperature Chemical Processes (ICEHT) \\ Patras, Greece
}

Received: $13 / 10 / 08$

Accepted: 14/01/09 *to whom all correspondence should be addressed: e-mail: lyberatos@chemeng.upatras.gr

\begin{abstract}
Anaerobic digestion of olive-mill wastewater (OMW) was carried out in a continuously fed mode bioreactor. The bioreactor was operated at different hydraulic retention times (HRTs), using OMW, either raw or pre-treated with white-rot fungi. Two different kinds of feed were tested in this process, one which was thermally treated and subjected to sedimentation, in order to remove the solids contained and the other without any physicochemical treatment (raw OMW). Thermally pretreated OMW did not allow a stable operation even at an HRT of $30 \mathrm{~d}$. Further pretreatment of the OMW with a white-rot fungus for removal of the contained phenolics, allowed a stable operation at an HRT of $30 \mathrm{~d}$. On the other hand, simple dilution of the raw wastewater, without any solids removal, lead to a stable operation at an HRT of $30 \mathrm{~d}$ and was accompanied by higher production of biogas. The presence of the solids in the OMW proved to be a determining factor for the stability of the process and could be attributed to a possible adsorption on the solids of hydrophobic compounds, such as long-chain fatty acids that are toxic to methanogens.
\end{abstract}

KEYWORDS: anaerobic digestion, OMW, white-rot fungi, pretreatment.

\section{INTRODUCTION}

Olive mill wastewater (OMW) is produced during the extraction of oil from the olive fruit by the traditional mill and press process. OMW has a wide range of characteristics depending on the type of the mill and the type of olive and equipment employed. Most of the mills in Greece use a 3-phase extraction process. However, some of the newer ones use the 2-phase extraction process. Traditional mills, where olive oil is produced in hydraulic oil press, are still present but to a limited extent. OMW has become a critical environmental problem in the Mediterranean area that accounts for approximately $95 \%$ of the world olive oil production, due to its high organic chemical oxygen demand (COD) concentration, and because of its resistance to biodegradation due to its high content in phenolic compounds (RamosComenzana et al., 1995). These compounds are responsible for its black color, and its phytotoxic and antibacterial properties (Capasso et al., 1992).

Various physico-chemical methods have been proposed for treating 3-phase OMW, including simple evaporation (Storm, 1989), flotation and settling (Fiestas Ros De Ursinos, 1981), vaporization and use of selected membranes (Boari et al., 1984; Bradley 1980), neutralization with addition of $\mathrm{H}_{2} \mathrm{SO}_{4}$, oxidation by $\mathrm{O}_{3}$ and Fenton reagent (Filipakopoulou et al., 1999), as well as reuse of the OMW by spreading onto agricultural soil as an organic fertilizer (Sabbah et al., 2004).

As far as biological processes are concerned, anaerobic biological processes are particularly advisable because of their well known advantages related to energy and chemicals saving and to the low production of sludge, especially when it comes to treatment of high COD wastewaters. The seasonal nature of the operation of olive mills (typically November to 
February) is not a disadvantage for anaerobic processes because the observed decay rates for methanogens are very low and a digester can be easily restarted after several months of shut-down (Lettinga et al., 1980). Although anaerobic digestion may be in principle used for reducing the high organic content of OMW, the presence of compounds toxic to methanogens in OMW appears to be a significant problem for the anaerobic digestion of OMW. One approach to the problem has been to sufficiently dilute the OMW to reduce the concentration of phenolics and fatty acids. In this case, the possibility of prior solids removal needs to be examined. A second approach has been the use of aerobic pretreatment of OMW to remove compounds that are toxic to methanogenic consortia. In particular, a preceding aerobic treatment of OMW with white-rot fungi, has been proposed as the most suitable microbial pretreatment process for the selective removal of phenolics (Blika et al., 2006; Fountoulakis et al., 2002).

Fungi have been used effectively in the pretreatment of OMW prior to anaerobic digestion. Hamdi (1991) found that pretreatment of OMW with A. niger more than doubled methane production in subsequent anaerobic digestion. In other studies, anaerobic digestion after pretreatment with $A$. niger removed over $60 \%$ of COD and resulted in high methane yields (Hamdi et al., 1992; Hamdi and Ellouz, 1993). Similarly, studies using A. terreus have demonstrated that aerobic pre-treatment greatly reduced the concentration of phenolics and significantly increased methane production (up to 23\%, Borja, 1995a; Martinez-Garcia et al., 2007 ) used the yeast $C$. tropicalis to aerobically pretreated OMW prior to anaerobic digestion. The combined system resulted in a $93 \%$ reduction in COD and degradation of $54 \%$ of the phenolic content of the OMW.

Two different white rot fungi have been used in the pretreatment of OMW prior to anaerobic digestion, with quite different results. $P$. chrysosporium reduced the COD of OMW, but apparently had little effect on polyphenolics, which remained in the effluent and inhibited subsequent methane production (Gharsallah et al., 1999). However, pretreatment with $G$. candidum reduced the COD, phenolic and volatile fatty acid content of OMW and increased substrate uptake during anaerobic digestion (Martin et al., 1993).

Borja et al., 1998) compared anaerobic digestion of OMW pretreated by two different fungi and a bacterium: G. candidum, A. terreus and Azotobacter chroococcum. These organisms decreased the phenolic concentration of OMW by $59 \%, 87 \%$ and $79 \%$, respectively. Subsequently, the kinetics of anaerobic digestion of OMW pretreated by G. candidum, $A$. terreus and A. chroococcum were enhanced 2.5-, 4.2- and 4.0-fold, respectively (McNamara et al., 2006).

The aim of the present study was to investigate the feasibility of alternative dilution and/or pretreatment processes (thermal pretreatment or pretreatment with white-rot fungus) for the anaerobic digestion of olive-mill wastewater in a stirred tank mesophilic digester.

\section{MATERIALS AND METHODS}

\subsection{Analytical methods and wastewater characterization}

Total suspended solids (TSS), volatile suspended solids (VSS), total and dissolved chemical oxygen demand (COD) and Kjeldahl nitrogen were determined according to Standard Methods (APHA, 1975). Total phenolic compounds were determined spectrophotometrically according to the Folin-Ciocalteu method (Waterman, 1994). For the determination of volatile fatty acids (VFAs) concentrations, acidified samples with $20 \% \mathrm{H}_{2} \mathrm{SO}_{4}$ were analyzed on a gas chromatograph (VARIAN CP-30), equipped with a flame ionization detector and a capillary column (Agilent technologies INC. $30 \mathrm{~m} \times 0.53 \mathrm{~mm}$ ). Helium was used as the carrier gas at a flow rate of $15 \mathrm{ml} \mathrm{min}^{-1}$. The methane concentration in the produced gas was quantified with a gas chromatograph (VARIAN STAR 3600) equipped with a thermal conductivity detector and a packed column (Poropack Q, 80/100-mesh) with nitrogen as carrier gas. The measurement of the produced gas volume was based on the displacement of oil in a U-tube gas flow meter.

The OMW used in this study was obtained from a typical Greek olive mill located in Patras (Achaia, Western Greece). The mill used the 3-phase decanter technology. Because of the seasonal operation of the mill, the OMW was obtained in December and maintained at $4{ }^{\circ} \mathrm{C}$ until the end of the experiments. The basic characteristics of the OMW are shown in Table 1. 
The COD value in OMW is very high and therefore, anaerobic treatment is a natural option for such wastewater. The nitrogen and phosphorus concentrations in the OMW used for the experiments were lower than what is required for anaerobic treatment. Therefore, nutrients, especially nitrogen, and also phosphorus and trace elements had to be added to the OMW. As far as nitrogen and phosphorus are concerned, $\left(\mathrm{NH}_{4}\right)_{2} \mathrm{HPO}_{4}$ was added to the OMW.

Table 1. Main characteristics of the used OMW

\begin{tabular}{lc}
\hline Parameters & Mean \\
\hline $\mathrm{pH}$ & $5.06 \pm 0.03$ \\
\hline $\mathrm{TSS}\left(\mathrm{g} \mathrm{l}^{-1}\right)$ & $32.73 \pm 1.83$ \\
\hline VSS $\left(\mathrm{g} \mathrm{l}^{-1}\right)$ & $31.37 \pm 1.74$ \\
\hline Total COD $\left(\mathrm{g} \mathrm{l}^{-1}\right)$ & $122.84 \pm 0.14$ \\
\hline Soluble COD $\left(\mathrm{g} \mathrm{l}^{-1}\right)$ & $63.84 \pm 3.55$ \\
\hline Phenols $\left(\mathrm{g} \mathrm{I}^{-1}\right)$ & $6.21 \pm 0.20$ \\
\hline TKN $\left(\mathrm{m} \mathrm{I}^{-1}\right)$ & $994 \pm 48.50$ \\
\hline Oil and grease $\left(\mathrm{g} \mathrm{l}^{-1}\right)$ & $10.78 \pm 1.39$ \\
\hline Total carbohydrates $\left(\mathrm{g} \mathrm{l}^{-1}\right)$ & $27.32 \pm 0.26$ \\
\hline Soluble carbohydrates $\left(\mathrm{gl}^{-1}\right)$ & $25.45 \pm 1.21$ \\
\hline Total phosphorus $\left(\mathrm{mg} \mathrm{l}^{-1}\right)$ & $343 \pm 42.17$ \\
\hline
\end{tabular}

The composition of the trace elements solution was as follows $\left(\mathrm{g} \mathrm{I}^{-1}\right): \mathrm{NH}_{4} \mathrm{Cl}$ (35.9), $\mathrm{MgCl}_{2} \cdot 6 \mathrm{H}_{2} \mathrm{O}$ (16.2), $\mathrm{KCl}$ (117), $\mathrm{CaCl}_{2} \cdot 2 \mathrm{H}_{2} \mathrm{O}$ (22.5), $\mathrm{CoCl}_{2} \cdot 6 \mathrm{H}_{2} \mathrm{O}$ (2.7), $\mathrm{MnCl}_{2} \cdot 4 \mathrm{H}_{2} \mathrm{O}$ (1.8), $\mathrm{CuCl}_{2} \cdot 2 \mathrm{H}_{2} \mathrm{O}$ (0.243), $\mathrm{ZnCl}_{2}$ (0.5), $\mathrm{Na}_{2} \mathrm{MoO}_{4} \cdot 2 \mathrm{H}_{2} \mathrm{O}$ (0.23), $\mathrm{H}_{3} \mathrm{BO}_{3}$ (0.513), $\mathrm{NiCl}_{2} \cdot 6 \mathrm{H}_{2} \mathrm{O}$ (0.2), $\mathrm{H}_{2} \mathrm{WO}_{4}(0.01), \mathrm{NaHCO}_{3}(5)$. $\left(\mathrm{NH}_{4}\right)_{2} \mathrm{HPO}_{4}$ was added to the OMW according to the COD:N:P ratio, 100:5:1. The high phenol concentration could also affect the treatability of the wastewater. The alkalinity of the wastewater was high $\left(2800 \mathrm{mg} \mathrm{l}^{-1}\right.$ as $\left.\mathrm{CaCO}_{3}\right)$ and enough for the high COD of the wastewater, thus no more alkalinity was added to the OMW.

\subsection{Fungal Trickling Flow Bioreactor}

The bioreactor consisted of a glass cylinder $(4.5 \mathrm{~cm}$ diameter $\times 28 \mathrm{~cm}$ height) packed with porous glass rings $(2 \times 2.5 \mathrm{~cm})$ on which the fungus had been immobilized. Further details may be found in (Blika et al., 2006). The bioreactor was operated in a sequential fed-batch mode with external aeration provided by an air pump. The feed was added at the top dropwise, trickled through the immobilized fungus and was recycled to the bioreactor via a peristaltic pump at a flow rate of $10 \mathrm{ml} \mathrm{min}^{-1}$. When maximum removal of phenolics was observed, the liquid part was removed and a new feed was added.

\subsection{Anaerobic reactor}

The anaerobic reactor used in this study was a 3 I (working volume) continuous stirred tank reactor (CSTR), made of stainless steel. A hot water jacket and a water recirculation bath were used to maintain the temperature of the digester in the mesophilic range $\left(35 \pm 1{ }^{\circ} \mathrm{C}\right)$. The reactor was completely covered in order to maintain anaerobic conditions, except for three ports (tubes) extending into the headspace of the reactor that allowed the effluent and the emitted gases to exit the reactor, the feed to be inserted in the reactor and the samples to be taken. Samples were taken three times a week and analysed for $\mathrm{pH}$, TSS, VSS, dissolved COD (d-COD), phenols, biogas production and composition and volatile fatty acids (VFAs).

The bioreactor operation was started up by addition of $3 \mathrm{I}$ anaerobic sludge taken from an active anaerobic digester of the Patras Sewage Treatment Plant. During the startup phase the system was operated batchwise for approximately 24 hours. 


\subsection{Thermal pre-treatment}

Thermal pre-treatment to $121^{\circ} \mathrm{C}$ for $30 \mathrm{~min}$ (sterilization) was followed by sedimentation for a few hours, until the temperature reached $30^{\circ} \mathrm{C}$. The supernatant was collected and filtered (Whatman No. 40) in order to remove the remaining solids.

\section{RESULTS AND DISCUSSION}

In the sequel, the experimental results from three different experiments are presented. Thus raw wastewater, as well as pretreated wastewater for solids removal or fungal pretreatment was used.

\subsection{Anaerobic digestion of raw OMW}

OMW used for this experiment was raw (without any physicochemical treatment). The anaerobic bioreactor was operated at two different HRTs, $30 \mathrm{~d}$ and $20 \mathrm{~d}$, respectively. The feed of the anaerobic bioreactor was diluted 1:1. Nutrients were added to the feed as referred above.
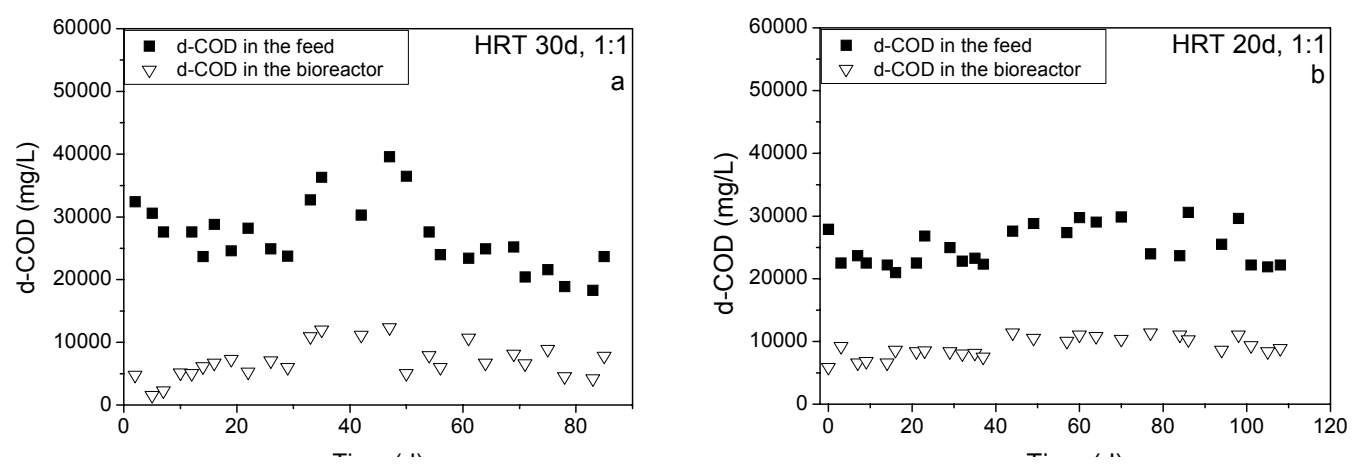

Figure 1. Influent and effluent COD values in anaerobic digestion of raw OMW at a) HRT of $30 \mathrm{D}$ and b) HRT of $20 \mathrm{~d}$

It is interesting to note that during these experiments the digester was operated with COD concentrations up to $30 \mathrm{~g} \mathrm{I}^{-1}$, as shown in Fig. 1, for a long time contrary to the anaerobic digestion of solids-free OMW. In spite of the gradual increase in the volumetric load in the digester, a satisfactory reduction of the COD concentration of the wastewater was obtained. This ranged between $66.5-83 \%$. It is probable that the observed stabilisation of the biological process in these experiments could be attributed to the presence of solids inside the digester.
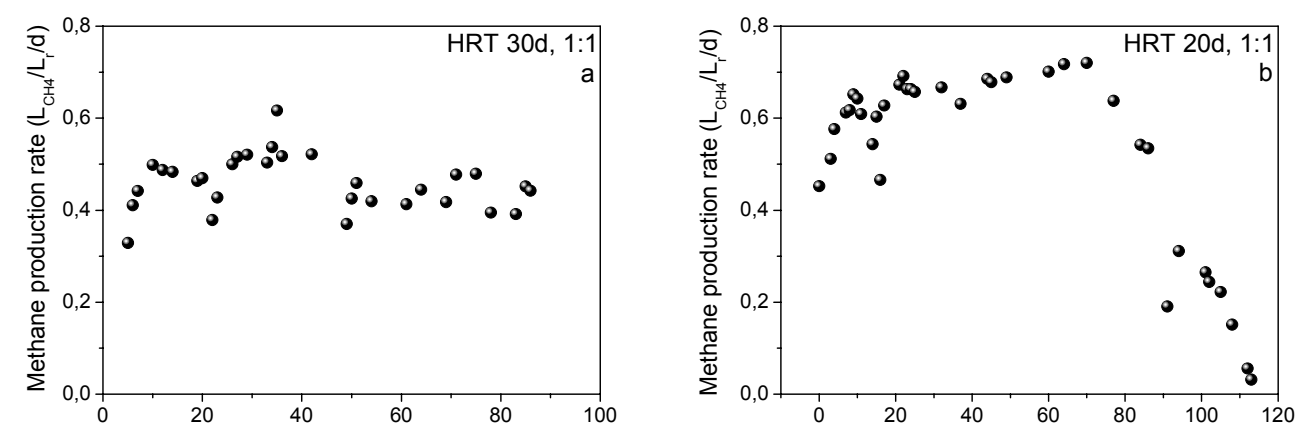

Figure 2. Methane production rate of raw OMW at a) HRT of $30 \mathrm{D}$ and b) HRT of $20 \mathrm{~d}$

Stable biogas production, at both HRTs, was achieved at about the $40^{\text {th }}$ day of continuous operation of the anaerobic digester as shown in Fig. 2. The higher methane production rate appearing in Fig. $2 \mathrm{~b}$ is attributed to the lower HRT of the anaerobic digester. The methane production rate remained stable until the end of the experiment concerning the digester which was operated at an HRT of $30 \mathrm{~d}$. At an HRT of $20 \mathrm{~d}$ a reduction of the methane production rate was observed at the end of the experiment which was accompanied by accumulation of VFAs (Fig. 3). 
Although the concentrations of acetic acid were low at both HRTs (Fig. 3), accumulation of propionic acid was observed at the beginning of the operation of the digester at the HRT of 30 d (Fig. 3a) but this was not accompanied by a pH decrease in the bioreactor. This propionate was gradually removed because the anaerobic bacteria were relatively uninhibited. The same was not observed at the HRT of $20 \mathrm{~d}$ (Fig. 3b). The accumulation of propionate began after the $80^{\text {th }}$ day of operation of the anaerobic bioreactor and still remained high until the end of the experiment.
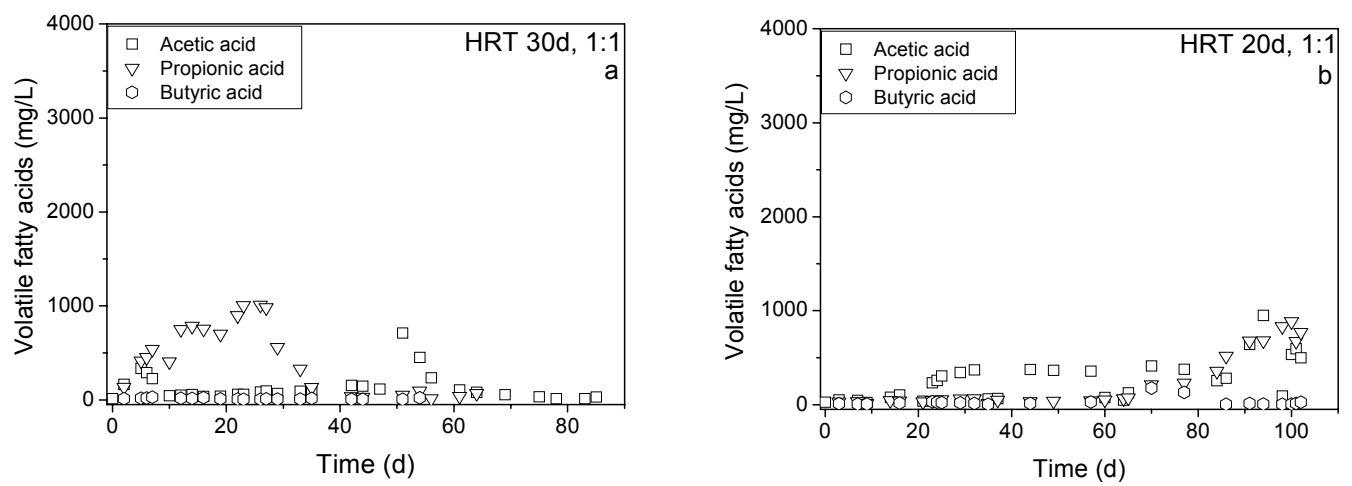

Figure 3. Volatile fatty acids accumulation in anaerobic digestion of raw OMW at a) HRT of $30 d$ and b) HRT of $20 d$

As the propionic acid was accumulated, the $\mathrm{pH}$ value was decreased (data not shown). Below $\mathrm{pH}$ 6.0, the accumulation of these acids causes inhibition of the acetogens, reducing their ability to degrade the heavier acids into acetic acid. Additionally, there is some evidence that high concentrations of propionic acid are inhibitory to methanogens (Brummeler et al., 1985).

\subsection{Anaerobic digestion of thermally pre-treated and clarified (from solids) OMW}

The OMW used in this experiment was thermally treated as referred in paragraph 2.4. This was done since in preliminary experiments we observed that such thermal pretreatment enhances solids separation substantially. The clarified OMW (total phenols $5.8 \mathrm{~g} \mathrm{I}^{-1}$, TSS 4.5 $\mathrm{g} \mathrm{I}^{-1}$, VSS $3.5 \mathrm{~g} \mathrm{I}^{-1}$, dissolved COD $60 \mathrm{~g} \mathrm{I}^{-1}$ ) was, diluted 1:1 with tap water, nutrients were added as explained above, and it was fed to a continuous digester, operated at an HRT of 30 d.

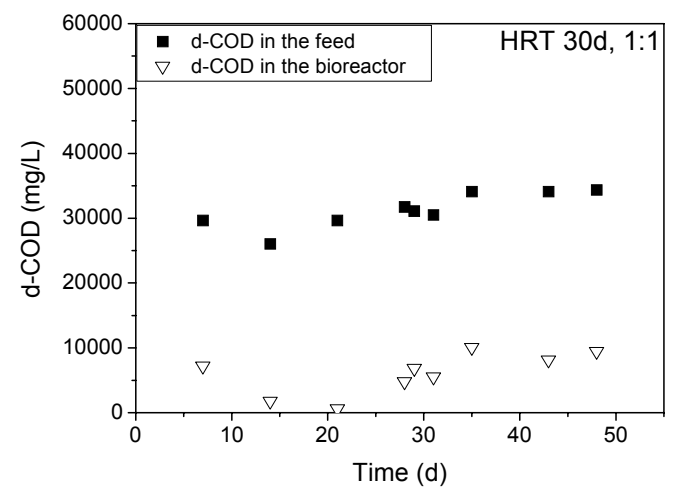

Figure 4. Influent and effluent COD values in anaerobic digestion of solid-free OMW

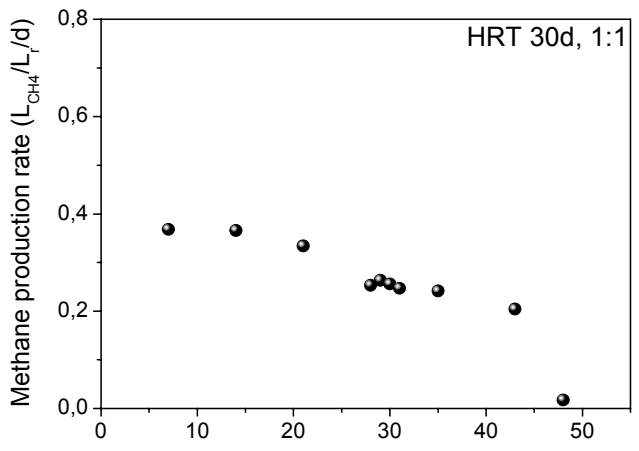

Figure 5. Methane production rate in the anaerobic digestion of solids-free OMW

The COD concentration in the feed was approximately $30 \mathrm{~g} \mathrm{I}^{-1}$. The evolutions of the influent and effluent COD, methane production rate and volatile fatty acids concentration during the anaerobic treatment are presented in figures 4, 5 and 6 respectively. Results showed that the COD reduction was approximately $73 \%$ during the period of digester operation (Fig. 4). However, the removal efficiency of COD showed a progressive decrease. This can be attributed to the low retention time in the reactor. The methane percentage in the biogas produced by the OMW was found to be in the range of $75 \%$ (data not shown). The 
biomethanization process was found to be stable during the first days of operation without any toxicity phenomenon. However, after the 20th day, a decrease in the biogas productivity and methane yield were observed (Fig. 5). This was accompanied by a pH decrease in the reactor and an accumulation of VFAs (Fig. 6). Several authors have reported that the inhibition of the

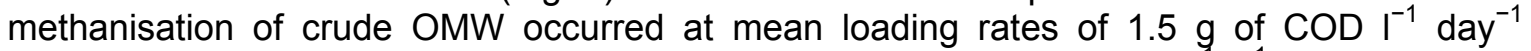
(Hamdi, 1991). In this experiment, although loading rate was $1 \mathrm{~g} \mathrm{of} \mathrm{COD} \mathrm{I}^{-1} \mathrm{~d}^{-1}$ inhibition of the methanisation occurred. Previous reports concluded that the presence of phenolics compounds in OMW inhibit the growth of certain microorganisms, particularly bacteria, and is the major cause, together with fatty acids, for the toxicity to methanogenic microorganisms of OMW (Perez et al., 1998).

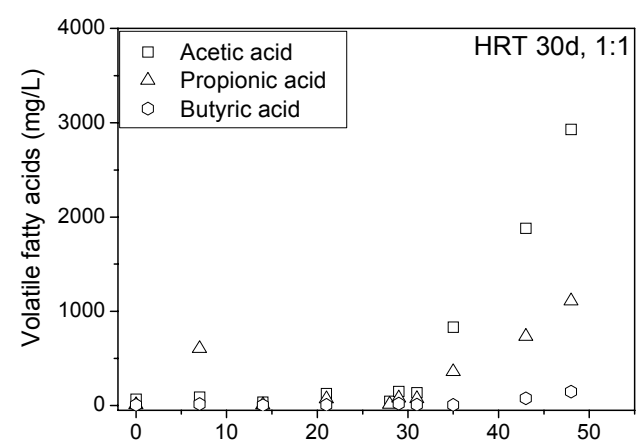

Figure 6. Volatile fatty acids accumulation in anaerobic digestion of thermally pretreated OMW

\subsection{Anaerobic digestion of OMW pre-treated with white-rot fungus}

The OMW used in this experiment was pre-treated with Pleurotus ostreatus P69, provided from the National Agricultural Research Foundation, Institute of Olive and Vegetable Crops, Kalamata, using the bioreactor described in paragraph 2.2. The anaerobic bioreactor was operated at an HRT of $30 \mathrm{~d}$. The feed of the anaerobic bioreactor was the pre-treated OMW (total phenols $3.5 \mathrm{~g} \mathrm{l}^{-1}$, TSS $5 \mathrm{~g} \mathrm{I}^{-1}$, VSS $4 \mathrm{~g} \mathrm{I}^{-1}$, dissolved COD $45 \mathrm{~g} \mathrm{I}^{-1}$ ), diluted with tap water at a ratio 1:1 after the pretreatment. Nutrients were added in the feed, after the pre-treatment, as referred above. The start up of the bioreactor was the same way as referred in paragraph 2.3.

At feed COD concentrations up to $23 \mathrm{~g} \mathrm{I}^{-1}$ (Fig. 7) the methane production was not inhibited. In fact, wastewater pre-treated with Pleurotus ostreatus had more stable methane production (Fig. 8). This shows that treatment by Pleurotus ostreatus decreases the toxicity of OMW to methanogenic bacteria. In fact, the phenolic compounds contained in pre-treated OMW were lower than in thermally treated OMW. This pre-treated OMW can therefore be easily treated by anaerobic digestion, with less toxicity, as we have observed in previous experiments, where treatment with immobilized fungus led to $75 \%$ decrease in the phenolics concentration (Blika et al., 2006).

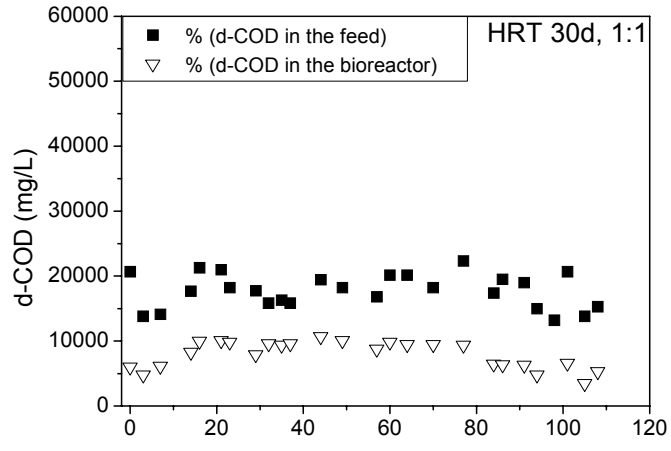

Figure 7. Influent and effluent COD values in anaerobic digestion of pretreated OMW

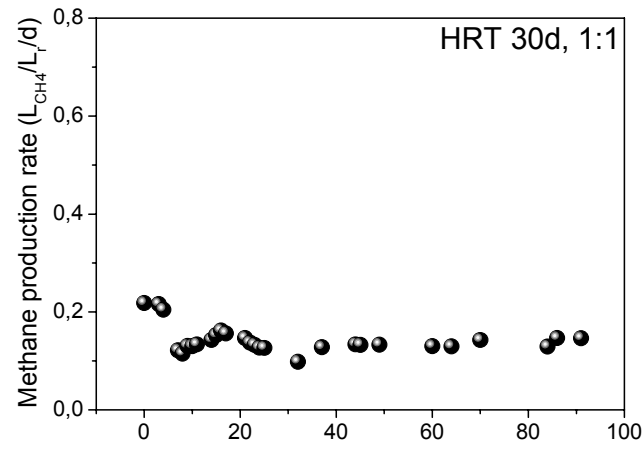

Figure 8. Methane production rate in anaerobic of pretreated OMW 
The rate of acetate production (Fig. 6) was faster than for the digestion of solids-free OMW. In the digestion of OMW pre-treated by Pleurotus ostreatus, acetate accumulated but was gradually removed because the methanogenic bacteria were relatively uninhibited.

The pre-treatment of OMW by fungi is significant since the process was more stable. Moreover, the accumulated acetate was removed during the anaerobic digestion when OMW was pre-treated by Pleurotus ostreatus, while this was not the case, when OMW was thermally treated.

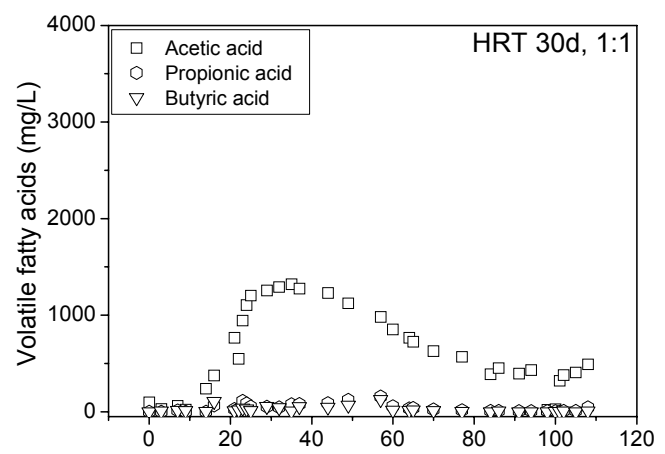

Figure 9. Volatile fatte acids accumulation in an aerobic digestion of pretreated OMW

\section{CONCLUSIONS}

Anaerobic digestion is the most effective process for the treatment of olive mill wastewater. However, dilution and/or some type of pretreatment are necessary to avoid toxicity of the phenolics on the methanogens.

Diluted 1:1 raw OMW, without any solids removal, can be effectively treated at an HRT of $30 \mathrm{~d}$, securing a stable high biogas yielding operation. The presence of the solids in the OMW proved to be a stabilising factor for the process and could be attributed to a possible adsorption on the solids of hydrophobic compounds, such as long-chain fatty acids that are toxic to methanogens.

Thermal pretreatment followed by sedimentation to remove the solids content, on the other hand, proved to be an undesirable type of pretreatment, as even at an HRT of $30 \mathrm{~d}$, the system was unstable. Further, biological pre-treatment with fungi may lead to a stable process at an HRT of $30 \mathrm{~d}$. This more stable process of the pretreated OMW digestion, may be partly attributed to the reduced COD content (by approximately $30 \%$ ), brought about by the biological pretreatment.

\section{ACKNOWLEDGEMENTS}

The authors would like to thank the General Secretariat for Research and Technology of Greece for funding this work under the grands 'COORDINATED PROGRAM SP-FP66' and 'Regional Innovation Pole for Western Greece (12PPK06)'. Also, they would like to thank Prof.A.Aivasidis, of the University of Thrace for providing the porous glass rings and Dr G.I. Zervakis for providing the Pleurotus strain.

\section{REFERENCES}

APHA, AWWA, WEF (1995) Standard methods for the examination of water and wastewater $19^{\text {th }}$ ed. Washington, DC, USA: American Public Health Association.

Blika P.S., Constantinidou G., Stamatelatou K., Kornaros M., Vayenas D.V., Zervakis G.I and Lyberatos G. (2006) Pretreatment of olive mill wastewater in a fungal trickling filter In: Proceedings of the third International Conference Water Resources In Mediterranean Basin, Tripoli, Lebanon.

Boari G., Brunetti A., Passino R. and Rozzi A. (1984) Anaerobic digestion of olive oil mill wastewaters, Agric Wastes, 10, 161-171. 
Borja R., Alba J., Garrido S.E., Martinez L., Garcia M.P., Incerti C. and Ramos Cormenzana A. (1995a) Comparative study of anaerobic digestion of olive mill wastewater (OMW) and OMW previously fermented with Aspergillus terreus, Bioprocess Engineering, 13, 317-322.

Borja R., Alba J., Garrido S.E., Martinez L., Garcia M.P., Monteoliva M. and Ramos-Cormenzana A. (1995b) Effect of aerobic pretreatment with Aspergillus terreus on the anaerobic digestion of olive-mill wastewater, Biotechnology and Applied Biochemistry, 22, 233-246.

Borja R., Alba J., Mancha A., Martin A., Alonso V. and Sanchez E. (1998) Comparative effect of different aerobic pretreatments on the kinetics and macroenergetic parameters of anaerobic digestion of olive mill wastewater in continuous mode, Bioprocess Engineering, 18, 127-134.

Bradley R.M. and Baruchello L. (1980) Primary waste in the olive oil industry, Effluent and Water Treatment Journal, 20(4), 176-177.

Brummeler E., Pol L., Dolfing J., Lettinga G. and Zehnder A. (1985) Methanogenesis in an upflow anaerobic sludge blanket reactor at $\mathrm{pH} 6$ on an acetate-propionate mixture, Applied of Enviromental. Microbiology, 49(6), 1472-1477.

Capasso R., Christinzio G., Evidente A. and Scognamiglio F. (1992) Isolation, spectroscopy and selective phytotoxic effects of polyphenols from vegetable waste waters, Phytochemistry, 31, 4125-4128.

Fedorak P.M. and Hrudey S.E. (1984) The effects of phenol and some alkyl phenolics on batch anaerobic methanogenesis, Water Res., 18, 357-361.

Fiestas Ros De Ursinos J.A. (1981) Differentes utilisations des margines. Recherches en cours, Resultats obtnus et applications, Seminaire international sur la vallorization des Sous-produits de l'olivier, Organisation des Nations unies pour l'alimentation et l' agriculture, Tunisie, 93-110.

Filipakopoulou T., Loukakis X., Zorpas A. and Vlyssides A.G. (1999) Treatment of waste water from table olive industries by Fenton's reactions, In: Proceedings of the second National Symposium of Chemical Engineers. Department of Chemical Engineering, University of Thessaloniki, Greece, 109-113.

Fountoulakis M.S., Dokianakis S.N., Kornaros M.E., Aggelis G.G and. Lyberatos G. (2002) Removal of phenolics in olive mill wastewaters using the white-rot fungus Pleurotus ostreatus. Water Res., 36, 4735-44.

Gharsallah N., Labat M., Aloui F. and Sayadi S. (1999) The Effect of Phanerochaete chrysosporium pretreatment of olive mill waste waters on anaerobic digestion, Resources, Conservation and Recycling, 27, 187-192.

Hamdi M. (1991) Effects of agitation and pretreatment on the batch anaerobic digestion of olive mill wastewater, Bioresour. Technol., 36, 173-178.

Hamdi M., Garcia J.L. and Ellouz R. (1992) Integrated biological process for olive mill wastewater treatment, Bioprocess Engineering, 8, 79-84.

Hamdi M. and Ellouz R. (1993) Treatment of detoxified olive mill wastewaters by anaerobic filter and aerobic fluidized bed process, Environmental Technology, 14, 183-188.

Lettinga G., Van Velsen A.F.M., Hobma S.W., de Zeeuw W. and Klapwijk A. (1980) Use of the upflow sludge blanket (USB) reactor concept for biological wastewater treatment, especially for anaerobic treatment, Biotech. \& Bioeng., 222, 699-734.

Martin A., Borja R. and Chica A. (1993) Kinetic study of an anaerobic fluidized bed system used for the purification of fermented olive mill wastewater, Journal of Chemical Technology and Biotechnology, 56, 155-162.

Martinez-Garcia G., Johnson A.C., Bachmann R.T., Williams C.J., Burgoyne A. and Edyvean R.G.J. (2007) Two-stage biological treatment of olive mill wastewater with whey as cosubstrate, International Biodeterioration \& Biodegradation, 59, 273-282.

McNamara C.J., Anastasiou C.C., O'Flahertyd V. and Mitchell R. (2007) Bioremediation of olive mill wastewater, International Biodeterioration \& Biodegradation, 61, 127-134

Perez J., De La Rubia T., Hamman O.B. and Martinez J. (1998) Phanerochaete flavido-alba laccase induction and modification of manganese peroxidase isoenzyme pattern in decolorized olive oil mill wastewaters, Appl. Environ. Microbiol., 64 2726-2729.

Ramos-Comenzana A., Monteolica-Sanchez M. and Lopez M.J. (1995) Bioremedation of alpechin, I. Bioterer Biodegr., 35, 249-268.

Sabbah I., Marsook T. and Basheer S. (2004) The effect of pretreatment on anaerobic activity of olive mill wastewater using batch and continuous systems", Process Biochemistry, 39, 19471951. 
Storm J. (1989) Evaporación del alpechín, Jornadas sobre innovación tecnologica medio ambiente y desarrollo, Instituto de la Grasa y sus Derivados, Sevilla, Spain.

Waterman P.G. and Mole S. (1994) Analysis of phenolic plant metabolites, In: Methods in ecology, Lawton J.H. and Likens G.E. (Eds.), Blackwell Scientific Publications, Oxford. 